\title{
The Sportization Process of the Equestrian Practices in Porto Alegre, Brazil
}

\author{
By Ester Liberato Pereira* \\ Carolina Fernandes da Silva \\ Janice Zarpellon Mazo
}

\begin{abstract}
This study aims to analyze how equestrian practices incorporated sportization elements, in Porto Alegre, from the mid-nineteenth to the early twentieth century. This research is based on information collected from newspapers and magazines being circulated in Porto Alegre during the period under analysis. Equestrian practices are cultural practices that are historically related to the formation of the sociocultural milieu in Porto Alegre. Throughout history, the horse being a symbol of the cultural identity of Rio Grande do Sul has been conceptually connected to various aspects of the economic and social life in the region. The partnership between man and animal is also present in moments of relaxation and enjoyment. Several sources revealed that within Porto Alegre's predominantly rural context, the first equestrian practices with sportization elements emerged in the second half of the nineteenth century. During this period, sports with horses were already popular.
\end{abstract}

Keywords: History of Sport, Turf, Horse racing, Clubs, Sportization

\section{Introduction}

The present study analyses a specific type of cultural practices related to the formation of the sociocultural setting of Porto Alegre, as well as of Rio Grande do Sul state: the equestrian sports. Brazil is a country of equestrian knowledge and traditions since the seventeenth century when equestrian tournaments started being held in the background of the Dutch occupation in the Brazilian north-east (Roessler and Rink 2006, Torres 2008). During the same period, there were strongholds of horse breeding in the so-called Jesuit Indian village in the state of Rio Grande do Sul, where the indigenous people had their first contact with these animals, using them as a means of transportation as well as for traction, auxiliary hunting, disputes over territory and mounting (Rubert 1998).

Horses and people in Rio Grande do Sul had been connected since the formation of the state, in the context of practices related to battles for conquest of territories, working activities, transportation and traction. It should not come as a surprise that such a partnership between man and animal was also present in the spheres of leisure and fun. During the early decades of the twentieth

\footnotetext{
${ }^{*}$ PhD Student, Federal University of Rio Grande do Sul, Brazil.

${ }^{\dagger}$ PhD Student, Federal University of Rio Grande do Sul, Brazil.

* Associate Professor, Federal University of Rio Grande do Sul, Brazil.
} 
century, in the capita of Rio Grande, equestrian practices showed the first signs of sportization in an environment in which the sports organization was associatively structured (Pereira 2012).

In Mazo and Gaya's research (Mazo and Gaya 2006), it was argued that, since the first occurrence of the sports associations phenomenon in Porto Alegre in the second half of the nineteenth century, horse-related sports practices had already appeared in the city; a quite indicative example are the horse races, known as "straight line horse races" and "turf", which is also a horse racing sport, but in a circular/elliptical track. Another practice widespread in Porto Alegre was the horseback bullfighting, a show that attracted a large audience (Pereira 2012).

In the present study, equestrian practices are understood as a cultural phenomenon presenting a peculiar diversity from the sociocultural context and the historical moment in which they occurred. According to Pereira (2012), equestrian practices related to the Creole equine breed sought to reproduce the agricultural activities in Rio Grande do Sul's pampa, which date back to the sixteenth century. Such practices, in addition to developing sportization elements, were incorporated into an established context and at some point, they served a distinct utilitarian purpose. Such is the case of the Golden Bridle Award which gradually evolved to acquire modern sports properties in the mid-twentieth century.

Taking the specificities of this background under consideration, this study attempts to provide reasoning regarding the process of the incorporation of sportization elements in equestrian practices in Porto Alegre during the period between the mid-nineteenth century and the early twentieth century. The research is centered in Porto Alegre, since this capital city was the center of horse activities of the state during the period under analysis.

\section{Materials and Methods}

In an attempt to conduct proper historical research, we contemplate the objective proposed from the side of a collection of information in printed sources such as the sports almanac Almanaque Esportivo do Rio Grande do Sul (Sports Almanac of Rio Grande do Sul), as well as the journals Revista Sportiva (Sportive Magazine) and Revista do Globo (Globe Magazine). The main Porto Alegre newspapers, namely Correio do Povo (Mail People) and Gazeta de Porto Alegre (Porto Alegre Gazette), circulating in the marked period were also surveyed, classifying the reports according to the editorial, the story and content. In addition, a thorough review of relevant books, research papers and dissertations was undertaken, aiming to delineate the historical context of the city in the time frame of this study. The information obtained was submitted to document analysis, according to Bacellar (2005) and Pimentel (2001), with the guidance of Elias and Dunning (1992) and Guttmann's (1978) ideas about modern sport and sportization. Equestrian practices were mainly treated as cultural practices that produce representations, 
as well as from the representations established by such practices there may emerge other cultural events identified or identifying social groups. The qualitative results of the analysis of the primary information sources are presented in the following section.

\section{Results}

\section{Straight Line Horse Races}

The acknowledgement of the importance of the multidimensional horserelated services in the everyday by Rio Grande do Sul' s people goes back to the very formation of this particular Brazilian state. The horse was already present in Rio Grande do Sul's pampa ${ }^{1}$ (Roessler and Rink 2006) even before the official founding of the first Portuguese settlement in this South captaincy, which took place in 1737 (Rozano and Fonseca 2005).

The horse was not present only in war, but was a fundamental part of the history of Rio Grande do Sul during the various historical phases of occupation, colonization and economic growth of the state. In rural areas, in rodeos, as a mount or traction, in peace and in war, the horse and the people from Rio Grande do Sul have always been connected.

Considering the engagement of people from Rio Grande do Sul in horserelated activities both in daily life and periods of territorial conquests, it is not surprising that, since the second half of the nineteenth century, the most popular fun and relaxation activities were also related to bullfighting, cavalhadas (a kind of rodeo) and horse racing. The latter specifically when it involved horses of the Creole breed had already evolved to being the most popular among such hobbies. This preference towards Creole horses, being the main companions of people from Rio Grande do Sul in their daily work tasks at the Pampa, stems from the fact that this particular breed originated in the Pampa region (Gianluppi et al. 2009).

In the countryside, the riders (either they were horsemen, soldiers and rural workers or even missionary Indians) used to challenge each other to horse races, determining who had in his occupation the fastest horse. From this habit, being common among the horse-riders, the so-called "straight line horse races" emerged. As innovative reasoning and logical connections between the "players" means and the "game's" outcomes underlie the rules of this practice, these types of horse race are currently considered cultural artifacts. The disputes occurred in straight line horse races tracks, under the measure of quadras ${ }^{2}$, in a track with the bare soil, that is, weeded, with flat land and small

\footnotetext{
${ }^{1}$ Rio Grande do Sul fields covered with excellent pasture, which serve to livestock, mainly cattle, horses and woolly (Nunes and Nunes 1994).

${ }^{2}$ The straight line tracks had their length in 300, 400 or 500 meters (Kilpp 2008), i.e., about two, three or even four quadras, respectively, since one quadra was equivalent to 128 meters (Rozano and Fonseca 2005). The riders always preferred a not very long straight line track, with a distance of about 260-400 meters, or two to three quadras at most. Bento (2002: 17) points out that even after the imposition of the metric system by Law n. 1157, in 1862, horse
} 
and narrow lanes (Rozano and Fonseca 2005). When the associated customs changed to allow the presence of spectators, all of them being men from all levels of the social pyramid (Bisson 2008), a considerable amount of money was often involved in the game through betting; eventually, straight-line horse racing evolved to being a business activity. After the Farroupilha Revolution (1835-1845), a new reconstruction period in the entire state of Rio Grande do Sul was in its infancy. Porto Alegre, the capital, was ahead in the resumption of development, with the construction of massive public buildings and other urban improvements. Nevertheless, faced with the challenge of modernization, people looked for a way to revive the old flame of Rio Grande do Sul's tradition: horse races. In this context, people continued to engage in traditional equestrian activities in the streets of both the center of the city and its outskirts, even before the inauguration of the first hippodrome in Porto Alegre. Regarding the event of the opening of this pioneering racetrack in 1880, The Gazette of Porto Alegre published: "[...] the Rio Grande is the Hungary of Brazil; it is the province in which everyone knows to walk on horseback and where horseback plays an important role in the social economy" (p. 16).

According to Rozano and Fonseca (2005), there are records that indicate that, in 1852, straight line horse races were taking place in Passo do Feijo (the ancient name of the current adjacent municipality of Porto Alegre) Alvorada (where, there still exists a neighborhood called Passo do Feijó). This indicates that the horse-related sports that pleased the people of the state of Rio Grande do Sul were also popular among the people in the capital. In his attempt to study and document people's attitudes towards equestrian practices through history, Franco (1998) finds that the horse races, favorite hobby of Rio Grande do Sul's Pampa people, was also popular in Porto Alegre since ancient times. The same author adds that Achilles Porto Alegre, in one of his essays, documented this equestrian practice taking place in Porto Alegre in the second half of the nineteenth century (Franco 1998). Achilles reported that the horse races, prior to the construction of hippodromes in the city, were held out in the open or in Campo da Várzea (in English, Lowland Field) (currently Farroupilha Park), near the Military College. Actually, this place seemed to be the preferred race track, as portrayed by Franco (1998): "The residents of the suburbs and neighboring villages, who had passion for horse racing, would gather there on Sundays and public holidays" (1998: 204). However, the Teresopolis Hill was best known in the city by the horse races hosted there (Franco 1998, Macedo 1973).

Taking under consideration the social background of the horse races in this Brazilian region, we can see that the inhabitants of Rio Grande do Sul admired them and considered them as being prestigious. After all, besides being a part of a highly profitable business involving large sums of money, they were also widely accepted forms of entertainment, with a massive amount of people

races were still held by quadras or turns for many years, resisting a legal obligation. Although it was expected to gradually replace the system of weights and measures throughout Brazil Empire in 10 years, this has not happened and took a few years until the Brazilians adapt to the new system. 
spending their weekend afternoons watching horse races in the capital as well as in many other cities in the interior of the State. In support for this argument, there are reports that document the existence of the horse racing tradition in Rio Grande do Sul since the very arrival of the first animals in its territory (Rozano and Fonseca 2005). Indisputably, the straight line horse races were "the sport and the preference game of the Pampa's man" (Rozano and Fonseca 2005: 82).

Since even the primary, most primitive forms of equestrian practices, a concern emerged regarding the possible ways in which the outcomes of the "games" could be certified and guaranteed of success, resembling to the characteristic modern pressure for the result, which, according to Guttmann (1978), is a sign of specialization. Thus, two specialized professions linked to straight line horse races emerged: the "composer" and the jockey. Even today, in the Pampa, the horse trainer, being responsible for the horses' diet and main training, is still called "composer". Thanks to the services provided by the composers, the horses were well cared for, being fed with corn and alfalfa made into hay and washed regularly and thoroughly. As part of the training being restricted to the animals by that time, the ready starts and the races had the intention of improving the horses' strength and speed.

A specialization of the horses competing in such races also started to develop: according to the physical qualities of both strength and speed required for winning the first place in a race, the most appropriate breed was considered to be this of the work horses, the Creoles. These horses, being of Iberian origin, came from the Arabic breeds. Over the centuries, they evolved to a specific breed of the Southern Cone (name commonly related to the southern part of South America) and highly valued in pastoral activities.

Following Guttmann's (1978) analysis with respect to the intricate system of support staff and the primary, secondary and tertiary movement, other specialties of horse racing can be identified according to the degree of involvement with the horse-racing practice itself. In addition to the jockey, the horse and the "composer", the juncture of the straight line horse races also involved bettors, usually being directly related to the countryside. Additionally, there were the "bowlers", the owners of bolichos, small assortment business houses which assembled tents (shelters), who engaged in selling food and drinks (Nunes and Nunes 1994: 26) and, of course, the spectators as well as the starting and arrival judges. In order to organize the contest, the judges used a tie or a flag to indicate the starting point of the race, judged which set of horse/rider had crossed the finish line first and conferred the relevant awards.

During the nineteenth century, the dominant leisure activities among the people of Porto Alegre were mostly restricted to indoor areas, being related to theater, music, dance, opera, card games and billiards. However, the German immigrants and their descendants, i.e. the German-Brazilians, were an exception, being more accustomed to gymnastics (Mazo and Gaya 2006), shooting games (Assman and Mazo 2012) and rowing (Silva et al. 2012), (Silva 2011). Such practices have been institutionalized through the 
organization of sports associations initiated by the members of the German community in Porto Alegre (Mazo and Gaya 2006).

During the transition from the late nineteenth century to the twentieth, the most popular leisure practice was still the ancient custom of the straight line horse races in Rio Grande do Sul, being consistent to the predominant rural structure in the city. According to Guttmann's theoretical analysis (1978) of the straight line horse races in Porto Alegre, contemporary equestrian practices did not include all those features necessary to be classified as sports. There is no evidence that these races were held in the context of neither highly bureaucratic networks nor institutionalized entities in the Therefore, their occurrence was not linked to the setting of a sports association, but rather depended on local residents' initiative. Along with the horse racing practices, the people of Porto Alegre used to engage in various types of leisure activities. In their study, Mazo and Gaya (2006) recorded specific alternatives to horse racing, such as swimming and athletics in Campo da Várzea. In this region, many sports and cultural events other than horse racing, such as bullfighting, took place.

\section{Bullfighting on Horseback}

Besides straight line horse races, other types of equestrian practices, such as bullfighting were regarded as primary activities of entertainment and leisure in Porto Alegre. In the last decades of the nineteenth century, bullfighting was held in Campo da Várzea, which housed the Bulls Circus or Bullring, located at the República Street (Macedo 1999). Here, bullfights were attended by an audience ranging from lower to upper classes (As Touradas 1910). Similar to an arena, the circus was made of wood, had no coverage and the cabins were at the top of the bleachers.

The practice of bullfighting is the most commonplace configuration of the Portuguese tauromachy, settling around the riders, who become the protagonists of the action (Molinié-Bertrand et al. 1999). In the past, bullfighting was regarded as an aristocratic art, and envisioned as a balanced combination of a leisure activity, an occasion to celebrate and exercise for the wars battles. However, these elements gradually vanished and the professional know-how of noble horsemen was demeaned to an opportunity for social recognition of the bankrupt bourgeoisie.

According to Guttmann (1978), bullfighting goes far back in time, the first indications of such practices being revealed by mosaics discovered in ancient Crete in which they are portrayed as parts of religious rituals. In the secularized context of Porto Alegre, that is, in a setting of no utilitarian purposes, the first bullfighting ever recorded occurred in 1875 and its purpose was to animate Sunday afternoons in Campo da Várzea. Franco (1998) states that initially these shows attracted a large audience, among which children and women also vibrated with the clashes between men and bulls.

Another interesting perspective in the sociological analysis of bullfighting emerges from the absence of equality in its practice. According to Guttmann (1978), in the core of bullfighting lies a status of inequality. In the center of the 
bullfighting event in Porto Alegre there was the confrontation between man and bull. In other words, it was a dispute of physical inequality by its very nature, with the bullfighter waiting for the bull's attack, then turning back and often kneeling, turning instantly with the purpose of capturing its horns just to remain firmly therein for a period of time.

In Porto Alegre, the most popular form of bullfighting resembled the Portuguese case in the sense that, the fighting took place on horsebacks (As Touradas 1910). Such bullfighting has possibly been preferred by Porto Alegre's people in the context of the cultural heritage of the Azorean immigration dating back to the origins of the city. In this version of bullfighting, the bull is no longer faced by a conventional bullfighter, but by a knight (or pick), aiming to repel the bull with a sword without letting it touch his horse.

Much skill is required from horse-riders in the practice of bullfighting, while at the same time the use of horses eliminated the inequality in strength between man and bull, since the man could exploit the advantages of confronting the bull on the back of a horse. All physical advantages arising therefrom including strength, height, agility and protection result in an approximation of a state of equality inherent in modern sports. In this context, the horse-rider and the bull have equal chances of gaining victory in the race. However, the physical differences between these two animals, bull and horse, still persist, as each animal depends on different qualities for winning. The bull has its pair of horns to defend itself while the horse relies on the technique of agile and skillful escape as its main defense in the battle. Certainly, these different qualities result in uneven performances in the arena.

Regarding the audience, Franco (1998) argues that, in the late nineteenth century, viewers found themselves disappointed by the animals lacking ferocity while competing with each other, often booing rather than cheering. Franco also cites a quotation from a journalist referring to the bulls as "one gentler than the other, legitimate soft calves and heifers" (Franco 1998: 103). The bullfight audiences' craving for more ferocious animals can exemplify what Elias (1992) describes as fun and pleasure-related tragedies and wars. Negative feelings of fear, grief, agony, anger and rage which would normally be avoided if possible in real life could be defused in the context of the bullfight. Such feelings being stimulated by sympathy and compassion, their expression is encouraged in this type of entertaining shows, such as witnessing the moment when a bullfighter gets ready to face a very fierce bull in the arena.

Elias (1992) suggests that the need for going through this particular kind of tension involved in exciting hobbies is psychologically explained on the basis of its relation to the imposed by modern life need to engage in various mental activities beyond those exhausted in the everyday. This form of excitement and emotional tension, often related to fear, sadness and other types of mimetic feelings, that the audience seeks constitute an essential ingredient of this type of recreational fun. Feelings elicited by an imaginary situation in the context of a leisure activity are similar to those triggered in real life situations that is what the "mimetic" term indicates. Bullfight audiences can enjoy the 
excitement of a mimetic confrontation between two living beings, evolving from one side to the other while at the same time being restricted within the controlled boundaries of an arena. This way their exogenous to the game emotional tension is relieved and their need for deep emotional experiences is covered on the basis of the balance between the anxiety of not knowing if something bad happens to the fighters and the certainty that no harm will occur to none of them. However, the simplistic "release of tension" or "recovery of labour" constitute hypotheses insufficient in explaining the aspect of tension/excitement realized through body movements. If this was the case, people would rather spend their free time just wandering around, lazing or resting than engaging in activities involving tension and excitement.

Turf

In the 1870s, the tamer captain Luis Jacome de Abreu and Souza came to the city with information regarding a new method of taming foals which disseminated quickly among the groups organizing and engaging in equestrian practices. According to Franco (1998), Luiz Jacome was a professor of riding whose intentions were centered in the creation of a thoroughbred horse to be specifically used in horse races and in the turf. The significant success and broad support that his initiative gained led to the development of a new type of horse racing only five years later, in 1877 . The proposed new races were highly valued among Porto Alegre's people, to evolve to the contemporary turf. In the context of these developments, the first hippodrome was built in the city.

The Porto Alegre Hippodrome was the first racetrack in the city, later named as Boa Vista and was located between the neighborhoods currently known as Parthenon and Santana (Bento 2002). The advent of races in circular or elliptical tracks along with the fact that horse racing had become a far more exciting show led to an increase in the wealth produced by the races, which in its own turn stimulated the demand for more appropriate places for them to be hosted (Bissón 2008).

After Boa Vista had been built, the construction of the Rio Grande Hippodrome already began in 1877. This racetrack entered both the international history of horse racing as well as the city's history as Menino Deus (in English, God Boy), taking its name by the neighborhood it was located in (Laços de Família 2010). This second hippodrome in Porto Alegre was officially inaugurated in 1881 on the site of an old fairground, at Getúlio Vargas Avenue where the headquarters of the Secretariat of State of Agriculture are located today (Rozano and Fonseca 2005).

Navegantes (translating to navigators in English) Hippodrome started its activities in 1891. It was located 500 meters from the tram line, within an ideal proximity for all the racetracks of the time. It had access by Prado Street (translating to Hippodrome Street), nowadays being known as Lauro Müller Street) in the Navegantes district. This neighborhood later hosted Renner, a company that promoted sports activities in general and football in particular among the employees of the region (Mazo et al. 2012). 
In 1894, Franco (1998) records the inauguration of another hippodrome, destined to centralize all the turf activities taking place in the city. It was the Independence Hippodrome, located in Moinhos de Vento (Windmills) District, in a land where now stands the Moinhos de Vento Park, popularly known as "Parcão" - in English, Big Park.

Thus, in the 1890s, there were four hippodromes operating in the city. The presence of several hippodromes which lasted for a quite long time enabled the development of Rio Grande do Sul's turf show, which eventually became one of the major sporting events in the early twentieth century, in Porto Alegre. Expectedly, the creation of hippodromes caused the straight line horse races to lose ground in the city (Mazo and Gaya 2006).

The turf, including the elements of luck and betting, still presents opportunities for fun and leisure, thus, comparing it with straight line horse races and turf reveals not only breaks, but also continuities. A similar evolution process can also be identified in other equestrian practices involving the Creole breed, being used in Rio Grande do Sul' $\mathrm{s}$ agricultural activities since the sixteenth century (Teixeira 2011). Those are the practices related to the so called Golden Bridle, which served a distinct utilitarian purpose being quite different in nature from the conventional pampa agricultural activities.

\section{Golden Bridle, Shot of Lasso with Horse}

The Golden Bridle Award was introduced 33 years ago by the Brazilian Association of Creole Horse Breeders (ACHB), an entity formally organized in 1932. The origin of Golden Bridle, which constituted a major activity of ACHB, goes back to the 1970s and started in the city of Jaguarão in Rio Grande do Sul. Prior to this period, only morphological exhibitions occurred, but due to concerns raised at the time about the Creole horse functionality, the First Functional Exhibition was established. In its primary version, the sports facilities were quite simple and the number of participants was limited. In the following years, the success and popularity of the event caught the attention of $\mathrm{ACHB}$, as this new practice combined functionality and morphology (História do Freio de Ouro 2012).

The Golden Bridle Award was established mainly to serve the goal of the promotion and enhancement of the Creole race horses. Based on the reproduction of real-field equestrian practices in an experimental environment, the most suitable animals are selected (Gianluppi et al. 2009). Within the scope of this screening procedure, the horses' morphology and functionality are evaluated by checking their performance in model races where the rider and horse are regarded as a single entity striving for victory. In this sense, those races are not solely typical leisure activities but they also serve the need of improving the agricultural production of the pampa. According to Guttmann (1978), they also exhibit the characteristics of modern sports. However, they lack the fundamental element of modern sports as proposed by Elias and Dunning (1992), the pursuit of pleasure through the practice itself. They ultimately serve what is identified as a utility purpose, namely the evaluation of 
the Creole horses' performance in order to improve the efficiency of the agricultural activities they are involved.

However, some types of equestrian shows included in the Golden Bridle, such as the Shot of Lasso with Horse mostly involving creole horses, are mainly performed for the sake of the audience's amusement. The goal of this lasso games is to capture a cow, standing within a distance of one hundred meters, with a leather string while riding a horse. The show, which does involve various sportization elements, emerged from the daily ranch routine of immobilizing the cows (Nunes and Nunes 1994, História do Freio de Ouro 2012) in Esmeralda during the 1950s, when the region was still a Vacaria district (Appio 2010).

In Porto Alegre, it is likely that this practice had been primarily supported and performed in the context of the first Gaucho Traditions Center (GTC) called the "35 GTC" and founded in 1948 (Ferreira 1987). According to Orreda (1999), the Centers were created for the purpose of diffusing local culture, aiming at both the preservation and dissemination of field practices and traditional artistic games and shows popular in Rio Grande do Sul.

As in other regions, in Rio Grande do Sul the shot of lasso with horse also involved Creole horses. Horses of this particular breed are the main companions of Rio Grande do Sul people in their daily tasks of pampa work as well as in their leisure activities. Quite illustrative of the importance these horses had for local people is an article published in Correio do Povo (Mail People in English) in 1912, according to which "the Creole horse is strong, agile, it's a rustic foolproof" (II Exposição 1912: 25). Considering these specific characteristics of these animals, it is clear that they conform to the criteria of efficiency and effectiveness of the pampa production, become an indispensable part of rural life in the region.

\section{Discussion}

Within the scope of Cultural History analysis, the present study of the information sources of the period under examination led to the conclusion that the people has always been connected with horses in Rio Grande do Sul. The use of horses has been a significant part of various types of daily activities over time following the whole development process of the region and adapting not only to the new conditions imposed by the gradual urbanization but also to the evolution of the social value attached to equestrian practices. The horse served as a weapon in times of war and a significant asset for the conquest of territories while in another historical period, the same animal was the symbol of economic growth, signifying the qualitatively new potential of working in the fields with the bovine cattle. Expectedly, this partnership between man and animal has also been present in the spheres of leisure and fun.

Following Guttmann's methodology (1978), elements indicating that an incipient sportization process was at work were identified in the primary version of the first straight line horse races in Porto Alegre. Along with races, 
bullfights were also among the first leisure activities involving horses in the region. However, based on Guttmann's theoretical conception of the characteristic of equality, it follows that the practice of bullfighting only started to approach the setting of a modern sport in the middle of the twentieth century.

In conclusion, the sportization of equestrian practices in the region emerges from and is developed within the context of the general use of the horse in leisure activities. Horse races are a very representative example of this process. In the case of the turf, even though it possesses all the features of a modern sport, it still involves the element of luck as in betting. The sportization process can also be identified in some of the equestrian practices related to the Creole breed. The practices included in the Golden Bridle conform to all the necessary conditions to be defined as modern sports according to Guttmann; however, they do not exhibit the fundamental characteristic proposed by Elias and Dunning (1992), the pursuit for pleasure through the practice itself. Finally, the equestrian practice involving the lasso based on the use of creole horses have purely recreational purposes.

\section{Conclusions}

As discussed in the present study, the equestrian practices involved in economic production and in times of war in southern Brazil were also performed for local people's entertainment. It can be argued that the incorporation of sportization elements in these traditional leisure practices involving horses indicates that they were exhibiting a sporting character from the outset. This conclusion is also supported by the theoretical concepts regarding sportization developed by Guttmann and Elias and Dunning being based on a universal and continuant design of the genealogy of modern sports.

\section{References}

II Exposição Agro-Pecuaria (II Agro-Livestock Exhibition) (08/05/1912) Correio do Povo (Mail People).

Appio F (2010) Tiro de Laço (Shot of Lasso). Coletânea Projeto Esperança.

As Touradas em Porto Alegre (Bullfighting in Porto Alegre) (13/02/1910) Correio do Povo (Mail People).

Assmann A, Mazo J (2012) As schützenvereine sociedades de atiradores de Santa Cruz do Sul: um tiro certo na história do esporte no Rio Grande do Sul (The schützenvereine societies shooters of Santa Cruz do Sul: a true shot in the history of sport in Rio Grande do Sul). Esporte e Sociedade (Sport and Society) 7: 11.

Bacellar C (2005) Uso e mau uso dos arquivos (Use and misuse of files). In Pinsky CB (edn.). Fontes Históricas (Historical Sources). São Paulo: Contexto.

Bento TR (2002) Remanescentes do turfe na cidade de Porto Alegre (Remnants of horse racing in Porto Alegre). Porto Alegre: Universidade Federal do Rio Grande do Sul. 
Bissón CA (2008) Moinhos de Vento: histórias de um bairro de elite de Porto Alegre (Windmills: stories of an elite district of Porto Alegre). Porto Alegre: Secretaria Municipal da Cultura: IEL.

Elias N (1992) A gênese do desporto: um problema sociológico (The genesis of sport: a sociological problem). In Elias N, Dunning E (edn.) A Busca da Excitação (The Quest for Excitement). Lisboa: Difel.

Elias N, Dunning E (1992) A Busca da Excitação (The Quest for Excitement). Lisboa: Difel.

Ferreira CD (1987) "35-CTG": o pioneiro do Movimento Tradicionalista GaúchoMTG ("35-CTG": the Pioneer of the Gaucho Traditionalist Movement-GTM). Porto Alegre: Martins Livreiro.

Franco SdC (1998) Porto Alegre: Quia Histórico (Porto Alegre: Historical Guide), $\left(3^{\text {rd }}\right.$ edn.). Porto Alegre: Editora da Universidade/UFRGS.

Gianluppi LDF, Bortoli ECd, Schvarz Sobrinho R, Falcão TF, Silva TN (2009) Agregação de valor em equinos da raça crioula: um estudo de caso (Value added in horses of Creole race: a case study). Archivos de Zootecnia (Animal Husbandry Files) 58(223): 4.

Guttmann A (1978) From Ritual to Record: The Nature of Modern Sports. New York: Columbia University.

História do Freio de Ouro (History of Golden Bridle) (2012) Retrieved from http:// www.racacrioula.com.br/site/content/historia/index.php?np=7. [Accessed: 20 June 2012]

Kilpp C (2008) Kriegerverein: a constituição da Sociedade de Guerreiros e das primeiras associações Teutônia/Estrela (1874/1950) (Kriegerverein: the establishment of the Warriors Society and the first associations in Teutonia/Star (1874/1950)). Porto Alegre: Universidade Federal do Rio Grande do Sul.

Laços de Família (Family ties) (2010) Recordar é viver (Remembering is living). Santo Amaro a Galope 12.

Macedo FR (1999) História de Porto Alegre (History of Porto Alegre), (3 ${ }^{\text {rd }}$ edn.). Porto Alegre: Editora da Universidade/UFRGS.

Macedo FR (1973) Porto Alegre: História e Vida de uma Cidade (Porto Alegre: History and Life of a City). Porto Alegre: Editora da Universidade Federal do Rio Grande do Sul.

Mazo JZ, Assmann AB, Dias C, Silva CF, Balbinotti CAA, Kilpp CE, Carmona EK, Pereira EL, Piccoli JCJ, Maduro PA, Vicari PR, Moraes RD, Martini SB, Frosi TO, Lyra VB (2012) Associações Esportivas no Rio Grande do Sul: lugares e memórias (Sports Associations in Rio Grande do Sul: Places and Memories). Retrieved from https://www.facebook.com/NEHME.RS?pnref=lhc.

Mazo J, Gaya A (2006) As associações desportivas em Porto Alegre (Brasil): espaço de representação da identidade cultural teuto-brasileira (Sports associations in Porto Alegre (Brazil): the space of representation of the German-Brazilian cultural identity). Revista Portuguesa de Ciências do Desporto (Portuguese Journal of Sport Science). 6(2): 205-213.

Molinié-Bertrand A, Duviols J-P, Guillaume-Alonso A (1999) Des taureaux et des hommes (Bulls and men). Paris: Iberica Collection, Presses de l'Université de Paris-Sorbonne.

Nunes ZC, Nunes RC (1994) Minidicionário Guasca (Mini Dictionary Guasca). Porto Alegre: Martins Livreiro.

Orreda JM (1999) MTG e CTGs, Movimento Tradicionalista Gaúcho e Centro de Tradições Gaúchas (GTM and GTCs, Gaucho Traditionalist Movement and 
Gaucho Traditions Center). Revista História em Debate (History in Debate Magazine).

Pereira E (2012) As práticas equestres em Porto Alegre: percorrendo o processo da esportivização (The equestrian practices in Porto Alegre: going through the process of sportivization). Universidade Federal do Rio Grande do Sul.

Pimentel A (2001) O Método da Análise Documental: seu uso numa pesquisa historiográfica (The Document Analysis method: its use in a historical research). 114.

Roessler M, Rink B (2006) Esportes Hípicos (Equestrian Sports) In Da Costa L, editor. Atlas do Esporte no Brasil (Sport Atlas in Brazil). Rio de Janeiro: CONFEF.

Rozano M, Fonseca Rd (2005) História de Porto Alegre: Jockey Club (History of Porto Alegre: Jockey Club). Porto Alegre: Nova Prova.

Rubert A (1998) História da Igreja no Rio Grande do Sul (Church History in Rio Grande do Sul). Porto Alegre: Edipucrs.

Silva C, Pereira E, Mazo J (2012) Clubes sociais: práticas esportivas e identidades culturais (Social clubs: sports and cultural identities). Licere (Belo Horizonte Impresso). 15: 20.

Silva C (2011) O remo e a história de Porto Alegre, Rio Grande do Sul: mosaico de identidades culturais no longo século XIX (The rowing and history of Porto Alegre, Rio Grande do Sul: mosaic of cultural identities in the long nineteenth century). Porto Alegre. Universidade Federal do Rio Grande do Sul.

Teixeira AL (2011) Cavalo crioulo: o símbolo do Rio Grande do Sul (Creole horse: the Rio Grande do Sul symbol). Porto Alegre: Viver no Campo.

Torres RV (2008) Cavaleiro \& cavalo na equitação (Rider \& horse in riding). Porto Alegre: Editora Rígel. 
